\title{
Systemic Immune Responses in Alzheimer's Disease: In Vitro Mononuclear Cell Activation and Cytokine Production
}

\author{
Mariavaleria Pellicanò $^{\mathrm{a}}$, Matteo Bulati ${ }^{\mathrm{a}}$, Silvio Buffa ${ }^{\mathrm{a}}$, Mario Barbagallo ${ }^{\mathrm{b}}$, Anna Di Prima ${ }^{\mathrm{b}}$, \\ Gabriella Misiano $^{a}$, Pasquale Picone ${ }^{\mathrm{c}}$, Marta Di Carlo ${ }^{\mathrm{c}}$, Domenico Nuzzo ${ }^{\mathrm{c}}$, Giuseppina Candore ${ }^{\mathrm{a}}$, \\ Sonya Vasto ${ }^{\mathrm{a}}$, Domenico Lio ${ }^{\mathrm{a}}$, Calogero Caruso ${ }^{\mathrm{a}, *}$ and Giuseppina Colonna-Romano ${ }^{\mathrm{a}}$ \\ ${ }^{\text {a }}$ Gruppo di Studio sull'Immunosenescenza, Dipartimento di Biopatologia e Biotecnologie Mediche e Forensi, \\ Università di Palermo, Italy \\ ${ }^{\mathrm{b}}$ Dipartimento di Medicina Clinica e delle Patologie Emergenti, Università di Palermo, Italy \\ ${ }^{\mathrm{c}}$ Istituto di Biomedicina e Immunologia Molecolare, CNR, Palermo, Italy
}

Accepted 27 February 2010

\begin{abstract}
To investigate the systemic signs of immune-inflammatory responses in Alzheimer's disease (AD), in the present study we have analyzed blood lymphocyte subsets and the expression of activation markers on peripheral blood mononuclear cells (PBMCs) from AD patients and age-matched healthy controls (HC) activated in vitro by recombinant amyloid- $\beta$ peptide (rA $\beta_{42}$ ). Our study of AD lymphocyte subpopulations confirms the already described decrease of the absolute number and percentage of B cells when compared to HC lymphocytes, whereas the other subsets are not significantly different in patients and controls. We report the increased expression of the activation marker CD69 and of the chemokine receptors CCR2 and CCR5 on T cells but no changes of CD25 after activation. B cells are also activated by $\mathrm{rA} \beta_{42}$ as demonstrated by the enhanced expression of CCR5. Moreover, $\mathrm{rA} \beta_{42}$ induces an increased expression of the scavenger receptor CD36 on monocytes. Some activation markers and chemokine receptors are overexpressed in unstimulated AD cells when compared to controls. This is evidence of the pro-inflammatory status of AD. Stimulation by $\mathrm{rA} \beta_{42}$ also induces the production of the pro-inflammatory cytokines IL- $1 \beta$, IL-6, IFN- $\gamma$, and TNF- $\alpha$, and of the anti-inflammatory cytokines IL-10 and IL-1Ra. The chemokines RANTES, MIP-1 $\beta$, and eotaxin as well as some growth factors (GM-CSF, G-CSF) are also overproduced by AD-derived PBMC activated by rA $\beta_{42}$. These results support the involvement of systemic immunity in AD patients. However, our study is an observational one so we cannot draw a conclusion about its contribution to the pathophysiology of the disease.
\end{abstract}

Keywords: Alzheimer's disease, chemokine, cytokine, PBMC, rA $\beta_{42}$

\section{INTRODUCTION}

Alzheimer's disease (AD) is a heterogeneous and progressive neurodegenerative disease that in Western

\footnotetext{
${ }^{*}$ Correspondence to: Calogero Caruso, MD, Gruppo di Studio sull'Immunosenescenza, Dipartimento di Biopatologia e Biotecnologie Mediche e Forensi, Università di Palermo, Corso Tukory 211, 90134 Palermo, Italy. Tel.: +39 0916555911; Fax: +39 0916555933; E-mail:marcoc@unipa.it.
}

societies accounts for the majority of clinical senile dementia. Since no early peripheral and reasonable signs of the disease have been identified so far, diagnosis can be made with firmness only upon brain autopsy. Moreover, no treatment is yet available to end or turn round the disease; existing drugs are only able to relieve symptoms for some time $[1,2]$.

Pathological changes in the AD brain include neuronal loss, senile plaques, and neurofibrillary tangles. Together with the presence of intraneural tangles, con- 
sisting of phosphorylated tau-proteins, senile plaques are the hallmark of the pathological diagnosis of AD. However, the increased production of amyloid- $\beta(\mathrm{A} \beta)$ from the amyloid- $\beta$ protein precursor and its brain accumulation and deposit in the senile plaques lead to inflammation and neuronal damage [3]. Depending on whether the 40th or the 42nd amino acid in C-terminus is the last of the $\mathrm{A} \beta$ protein, it consists of two major forms, $\mathrm{A} \beta_{40}$ and $\mathrm{A} \beta_{42}$. The latter tends to cluster into oligomers, forming $\mathrm{A} \beta$ fibrils that deposit as microstructures, amyloid plaques, and it is the predominant form that accumulates in the brain parenchyma of $\mathrm{AD}$ patients. Senile plaques result from the accumulation of several other proteins and an inflammatory reaction around deposits of amyloid. In addition, plaques contain dystrophic neurites, activated microglia, and reactive astrocytes. Aggregated amyloid fibrils and inflammatory mediators secreted by microglial and astrocytic cells contribute to neuronal dystrophy $[3,4]$.

Inflammation clearly occurs in pathologically vulnerable regions of the AD brain, and it does so with the full complexity of local peripheral inflammatory responses [5]. The microglia activation can be due to local or systemic inflammation. In fact, a strong local inflammatory stimulus such as a previous head trauma is a risk factor for $\mathrm{AD}$ and several epidemiological studies clearly show that blood elevations of acute phase proteins, markers of systemic inflammatory stimuli, may be risk factors for cognitive decline and dementia. Furthermore, in experimental animals chronic systemic inflammatory response induced by lipopolysaccharide administration also induces glial activation. After activation, the microglia cells modify their morphology and become tissue macrophages producing inflammatory mediators $[3,6]$. Accordingly, case-control studies clearly demonstrate the role of inflammatory genes in $\mathrm{AD}[3,7,8]$. In particular, two recent meta-analyses by our group have underscored the role of cytokine polymorphisms in AD susceptibility, hence indicating the role of immune-inflammatory responses in $\mathrm{AD}[9,10]$.

$\mathrm{A} \beta$ induces a local immune response involving glial cells and astrocytes. The innate immunity tries to clear $\mathrm{A} \beta$ and induces the production of inflammatory proteins such as complement factors, acute-phase proteins, pro-inflammatory cytokines, and chemokines that will be chronically produced and can induce neurotoxicity $[5,11]$.

Although much evidence suggests the involvement of a systemic immune response in AD, it is poorly characterized [12]. Indeed, blood derived cells seem to accumulate in the AD brain [13], while other studies have shown changes in the distribution and reactivity of immune cells in the blood [12,14-16]. As reviewed by Britschgi and Wyss-Coray [12], many studies have shown that there is communication between central and systemic immune responses. In particular neuroinflammation induces the efflux of central nervous system (CNS) proteins, such as $\mathrm{A} \beta$, or inflammatory mediators across the blood-brain-barrier (BBB); this may cause systemic immune reaction and recruitment of myeloid or lymphocytic cells into the CNS [12]. Thus, communication between the CNS and immune system in AD could influence both the lymphocyte distribution in the blood and the production of immune mediators [12]. Indeed peripheral blood mononuclear cells (PBMCs) from $\mathrm{AD}$ patients produce higher levels of some cytokines, such as interleukin (IL)- $1 \beta$ and IL-6 compared to PBMC from control subjects [17]. Other studies have shown that $\mathrm{A} \beta$ stimulates macrophage inflammatory protein (MIP)- $1 \alpha$ overexpression on peripheral T cells and its receptor CCR5 expression on brain endothelial cells for T cells crossing BBB [18].

In addition, the production of Regulated on Activation, Normal T Expressed and Secreted (RANTES) by AD PBMCs seems to increase after stimulation by $\mathrm{A} \beta$ [19]. Moreover, an immune disregulation was recently documented as dramatic alterations on CD4+ subsets in patients with mild $\mathrm{AD}$ have been reported. In particular, decreased percentages of naïve cells and an increase of memory cells, an increased number of CD4+ lymphocytes that lack the co-stimulatory molecule CD28, and a reduction of CD4+CD25 ${ }^{\text {high }} \mathrm{T}$ regulatory cells (Treg) have been observed [20].

These data suggest a significant involvement of both the innate and acquired immunity in AD patients, although there are not enough data to determine if these are the causes or the consequences of the disease. To gain insight into this topic, we have investigated some basic immune parameters in patients with $\mathrm{AD}$, and we have performed in vitro activation studies of AD PBMCs with recombinant $\mathrm{A} \beta\left(\mathrm{rA} \beta_{42}\right)$ to evaluate cellular reactivity to the peptide and the cytokine and chemokine production.

\section{MATERIALS AND METHODS}

\section{Subjects}

Diagnosis of probable AD was according to standard clinical procedures and followed the NINCDS/ADRDA and DSM-III-R criteria $[21,22]$. Cognitive perfor- 
mance and alterations were measured according to the Mini Mental State Examination (MMSE) and the Global Deterioration Scale. All AD cases were defined as sporadic because their family history did not mention any first-degree relative with dementia. The population of AD consisted of 40 patients from Sicily (27 women and 13 men; age range: 64-86 years; mean age: $78.4 \pm 7.6)$. AD patients included in the study did not present major co-morbidity such as cancer, symptomatic (present or previous) cardiovascular diseases, and major inflammatory diseases such as autoimmunity and infections. Eighteen of them were under treatment for hypertension and/or diabetes with drugs not known to affect the immune system. According to MMSE, 16 patients were affected by severe dementia $(<17)$, whereas the remaining 24 were affected by moderate grade of dementia $(>17<24)$. Patients with vascular dementia were not included in the study. Since treatment with acetyl-cholinesterase inhibitors may modulate cytokine expression [23], patients were included before starting that therapy. Healthy controls (HC) were 25 unrelated individuals (15 women and 10 men; age range: 63-85; mean age $77.5 \pm 7.2$ ) randomly selected from a retirement home. These subjects had complete neurological examinations and were judged to be in good health based on their clinical history and blood tests (complete blood cell count, erythrocyte sedimentation rate, glucose, urea nitrogen, creatinine, electrolytes, $\mathrm{C}$ reactive protein, liver function tests, iron, proteins, cholesterol, triglycerides). The controls were collected from the same population as the patient cohort. The University Hospital Ethics Committee approved the study, and informed consent was obtained from all guardians of patients and controls according to Italian law.

Whole blood was collected by venopuncture in vacutainer tubes containing ethylenediamine tetraacetic acid. The samples were kept at room temperature and used within $2 \mathrm{~h}$ for the various experiments. Lymphocyte subsets were analyzed in $40 \mathrm{AD}$ and $25 \mathrm{HC}$. Cell cultures for activation and cytokine production were performed on PBMCs from $18 \mathrm{AD}$ and $15 \mathrm{HC}$ randomly selected, taking into account gender, age range, and the ratio between severe and moderate $\mathrm{AD}$. In fact, we studied 11 patients affected by moderate AD (4 men and 7 women, mean age $79.6 \pm 1.3), 7$ patients affected by severe AD ( 2 men and 5 women, mean age $81.0 \pm$ $1.5)$, and $15 \mathrm{HC}$ ( 6 men and 9 women, mean age $78.5 \pm$ 1.2).

\section{Preparation and characterization of $r A \beta_{42}$}

Isolation and purification of $\mathrm{rA} \beta_{42}$ were performed as described by Carrotta et al. [24]. To obtain small oligomers, $\mathrm{rA} \beta_{42}$ was dissolved in double-distilled $\mathrm{H}_{2} \mathrm{O}\left(\mathrm{ddH}_{2} \mathrm{O}\right)$ to a final concentration of $1.4 \mathrm{mM}$ and incubated at $37^{\circ} \mathrm{C}$ for $96 \mathrm{~h}$. Immediately after dissolution (time 0 ), and after incubation, aliquots were taken and stained adding thioflavin-T (ThT) at a final concentration of $70 \mu \mathrm{M}$ and applied to microscope slides [25]. The presence of aggregates with dimensions in the range of micrometers was visualized with the fluorescence optics of an Axioscop 2 microscope (Zeiss, USA). The images were captured using an Axiocam digital camera interfaced with a computer. Moreover, $\mathrm{rA} \beta_{42}$ at time 0 , and after incubation at $37^{\circ} \mathrm{C}$ for $96 \mathrm{~h}$, was analyzed by Western blot. Analysis of the samples was carried out using SDS-PAGE, and after running, the gel was transferred to nitrocellulose and the filter was incubated with anti-Histidine (anti-His) 1:5000 (Pierce, Rockford, IL, USA) [24].

\section{Cell cultures}

PBMCs were separated by centrifugation with Ficoll-Lympholyte (Cedarlane Laboratories Limited, Ontario, Canada) and washed twice in PBS. Viability was assessed by trypan blue dye exclusion. The viable cells (95-98\% of the preparation) were re-suspended at the concentration of $1 \times 10^{6} / \mu \mathrm{l}$ in complete medium composed of RPMI 1640 (Euroclone, Devon, UK) supplemented with $10 \%$ heat-inactivated fetal calf serum (Euroclone), 1\% penicillin/streptomycin, $10 \mathrm{mM} \mathrm{HEP-}$ $\mathrm{ES}$, and $1 \mathrm{mM}$ L-glutamine.

Cells were cultured in 24-well flat-bottom plates at $1.5 \times 10^{6}$ cells per well in RPMI medium. The PBMCs were either unstimulated or stimulated by oligomeric $\mathrm{rA} \beta_{42}(10 \mu \mathrm{g} / \mathrm{ml})$ obtained as described above. For the chemokine receptor expression study, the PBMCs were either unstimulated or stimulated by phytohaemagglutinin (PHA) $(3 \mu \mathrm{g} / \mathrm{ml})$, anti-CD3 ( $\alpha$-CD3) $(1 \mu \mathrm{g} / \mathrm{ml})$, $\mathrm{rA} \beta_{42}(10 \mu \mathrm{g} / \mathrm{ml})$, for $48 \mathrm{~h}$ at $37^{\circ} \mathrm{C}$ in a humidified $5 \%$ $\mathrm{CO}_{2}$ atmosphere. The cells were then collected and used for flow cytometry.

\section{Flow cytometry}

In order to evaluate the Tlymphocyte subsets in both $\mathrm{AD}$ patients and $\mathrm{HC}$, fresh samples were stained using the following monoclonal antibodies: anti-CD3, antiCD4, anti-CD8, anti-CD16, anti-CD19, anti-TCR $\gamma \delta$.

In order to evaluate the activation of PBMC obtained from $\mathrm{AD}$ patients and $\mathrm{HC}$, the in vitro cultured cells were stained as follows: anti-CD2 $5_{F I T C}$ /anti-CD $3_{P E}$ /anti-CD $19_{P E C y 5}$, anti-CD69 ${ }_{F I T C}$ /anti-CD ${ }_{P E}$ /anti- 


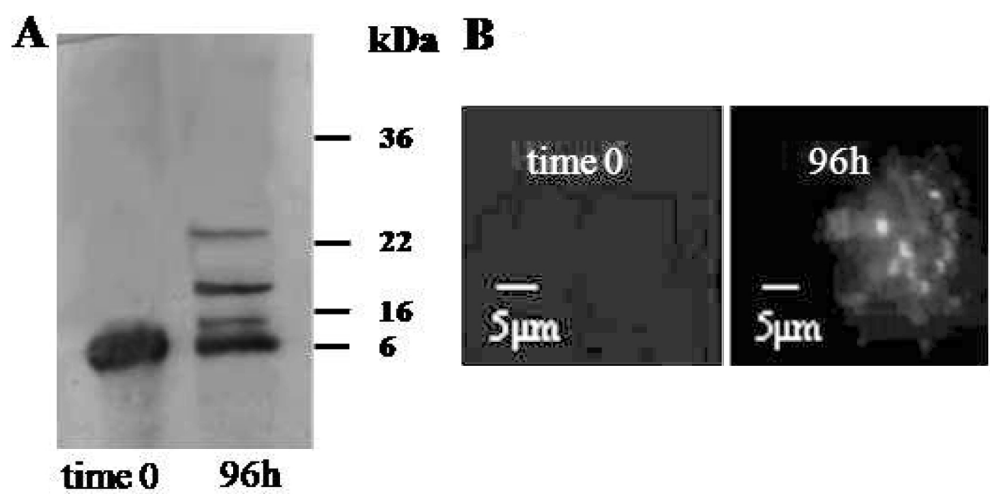

Fig. 1. Characterization of $\mathrm{rA} \beta_{42}$. A) Western blot of $\mathrm{rA} \beta_{42}$ incubated with anti-His, immediately after dissolution in ddH $\mathrm{H}_{2} \mathrm{O}(\mathrm{time} 0$ ) and after incubation for $96 \mathrm{~h}$ at $37^{\circ} \mathrm{C}$. On the right, molecular weight standards are indicated. B) Staining with ThT. Fluorescence images of representative areas of the observation field at time 0 and at $96 \mathrm{~h}$.

CD19 ${ }_{P E C y 5}$, anti-HLADR ${ }_{F I T C} /$ anti-CD19 ${ }_{P E} /$ anti$\mathrm{CD} 80_{P E-C y 5}$ and anti-CD36 ${ }_{F I T C} /$ anti-CD $14_{P E}^{+} /$ $\mathrm{CD} 80_{P E-C y 5}$. The activation-induced expression of chemokine receptors was evaluated by staining cultured cells with the following monoclonal antibodies: anti-CD192 (CCR2) ${ }_{\text {AlexaFluor }}{ }_{647}$, antiCD193 (CCR3) $P E$ and anti-CD195 (CCR5) $P E-C y 5$ on $\left.\mathrm{B}\left(\mathrm{CD}^{+}\right)^{+}\right)$and $\mathrm{T}\left(\mathrm{CD}^{+}\right)$cells. All monoclonal antibodies were directly coupled either to fluorescein isothiocyanate (FITC), R-phycoerythrin (R-PE), phycoerytrin-Cyanine 5 (PE-Cy5), or Alexa Fluor ${ }^{\circledR}$ 647 (Pharmingen, BD Bioscience, Mountain View, CA, USA).

All the measurements were made with a FACSCalibur flow cytometer (Becton Dickinson, San Jose, CA, USA) with the same instrument setting. At least $10^{4}$ cells were analyzed using CellQuestPro (Becton Dickinson, San Jose, CA, USA) software.

\section{Cytokine production assay}

The supernatants of the cultured PBMCs were collected and the following cytokines and chemokines were evaluated using a Bio-Plex kit (BioRad, Munich, Germany): IL-1 $\beta$, IL-1ra, IL-2, IL-4, IL-5, IL-6, IL7, IL-8, IL-9, IL-10, IL-12, IL-13, IL-15, IL-17, basic fibroblast growth factor (BFGF), eotaxin, granulocyte colony-stimulating factor (G-CSF), granulocytemacrophage colony-stimulating factor (GM-CSF), interferon(IFN)- $\gamma$, IFN- $\gamma$-inducible protein (IP)-10, monocyte chemoattractant protein (MCP)-1, MIP-1 $\alpha$, MIP$1 \beta$, platelet-derived growth factor-bb (PDGF-bb), RANTES, tumor necrosis factor (TNF- $\alpha$ ), and vascular endothelial growth factor (VEGF). $50 \mu \mathrm{l}$ per sample were analyzed on the Luminex 100 (BioRad) according to manufacturer's instructions.

\section{Statistical analysis}

Values (percentage or MFI), given as the mean \pm SEM, were compared using one-way analysis of variance (ANOVA). Differences were considered significant when a value $<0.05$ was obtained by comparison of the two different groups.

\section{RESULTS}

Characterization of $r A \beta_{42}$

To confirm that $\mathrm{rA} \beta_{42}$, prepared as previously described, forms oligomers in vitro, an aliquot of the samples at time 0 and at $96 \mathrm{~h}$ obtained as described in the previous section was incubated with anti-His. As shown in Fig. 1A, on the basis of the molecular weight of the detected bands, we established that only monomers were present in the sample at time 0 , and different small oligomers (ranging from 12 to $24 \mathrm{kDa}$ ) in the sample at $96 \mathrm{~h}$. Furthermore, after staining with ThT no visible structures in the sample at time 0 were detectable, whereas, small structures of dimensions up to $2 \mu \mathrm{m}$ in the $96 \mathrm{~h}$ sample were present (Fig. 1B). Therefore, the preparations used in our experiments were made up of oligomers.

\section{Lymphocyte subsets}

Table 1 shows the percentage and the absolute number of the main lymphocyte subpopulations evaluated in $25 \mathrm{HC}$ and $40 \mathrm{AD}$ patients. As shown, and as previously reported by others [26-28], we report a significant decrease in the percentage and absolute number 
Table 1

Lymphocyte subpopulations in $40 \mathrm{AD}$ subjects and $25 \mathrm{HC}$. Data are expressed as Mean \pm SD of the percentage and as absolute number

\begin{tabular}{lcccc}
\hline Subpopulations & $\mathrm{HC} \%($ Mean $\pm \mathrm{SD})$ & $\mathrm{HC}($ Absolute number/ $\mu \mathrm{L})$ & $\mathrm{AD} \%($ Mean $\pm \mathrm{SD})$ & $\mathrm{AD}(\mathrm{Absolute}$ number$/ \mu \mathrm{L})$ \\
\hline $\mathrm{CD}^{+}$ & $67.3 \pm 11.8$ & $1196 \pm 444$ & $68.4 \pm 9.2$ & $1260 \pm 420$ \\
$\mathrm{CD}^{+}$ & $44.3 \pm 9.6$ & $801 \pm 310$ & $45.7 \pm 8.9$ & $845.6 \pm 340$ \\
$\mathrm{CD}^{+}$ & $20.0 \pm 10.5$ & $373 \pm 214$ & $21.0 \pm 8.9$ & $361 \pm 160$ \\
$\mathrm{CD}^{+} 9^{+}$ & $9.8 \pm 5.3$ & $184 \pm 128$ & $7.0 \pm 3.7^{*}$ & $110 \pm 54^{*}$ \\
$\mathrm{CD}^{-} \mathrm{CD}^{+} 6^{+}$ & $17.2 \pm 9$ & $350 \pm 195$ & $15.7 \pm 6.7$ & $319 \pm 165$ \\
$\gamma \delta^{+}$ & $3.0 \pm 3.3$ & $45 \pm 55$ & $2.5 \pm 1.8$ & $54 \pm 39$ \\
\hline
\end{tabular}

Significance has been evaluated by ANOVA test. $\mathrm{AD}$ vs. $\mathrm{HC}^{*} p=0.01$.
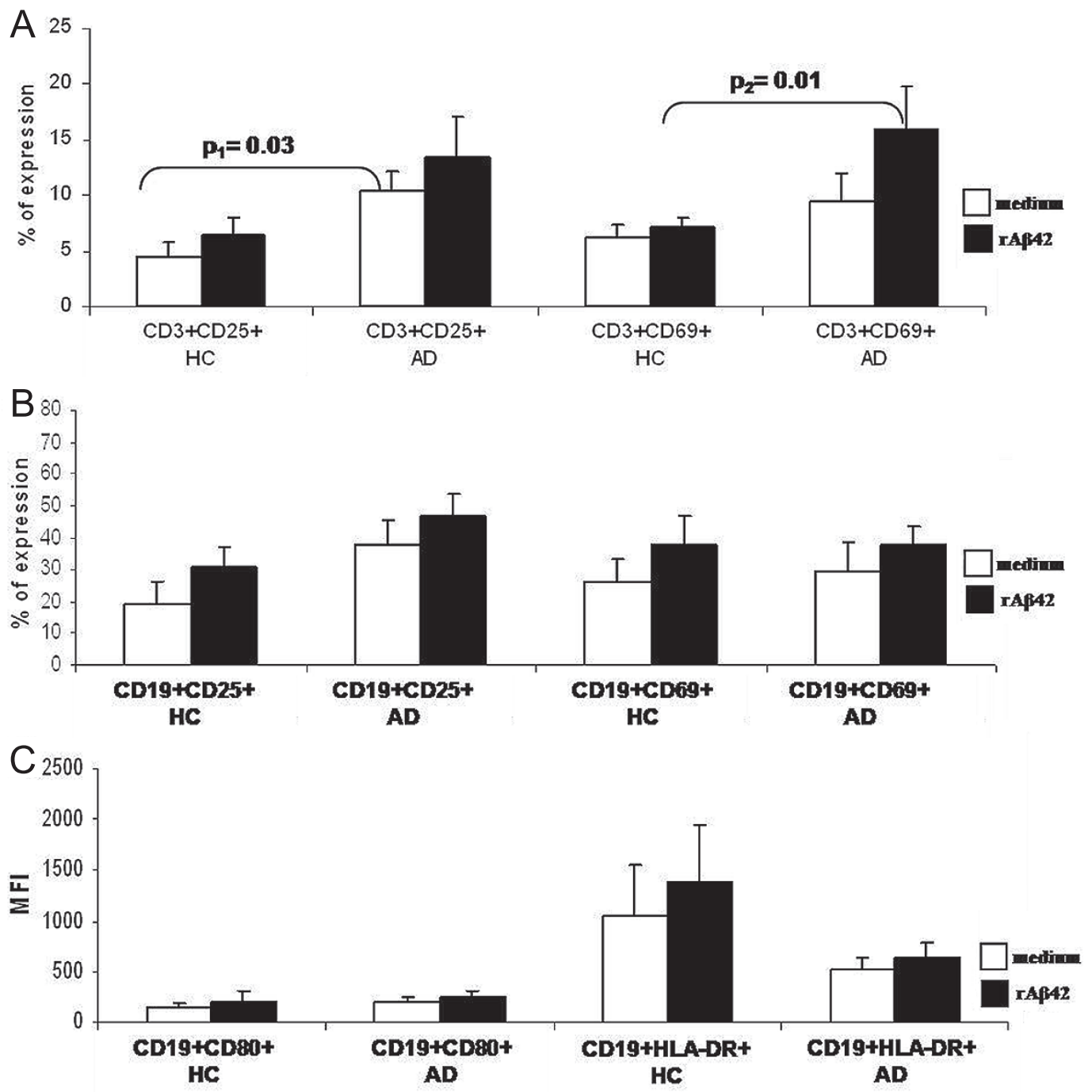

Fig. 2. Percentage (Mean \pm SEM) of expression of early activation markers CD25 and CD69 on T (CD3+) (panel A) and B (CD19+) (panel B) cells of $\mathrm{HC}(n=15)$ and $\mathrm{AD}$ subjects $(n=18)$ cultured in medium (white) or with rA $\beta_{42}$ (black). Panel C shows the MFI (Mean \pm SEM) of expression of CD80 and HLA-DR on B cells of HC $(n=15)$ and AD subjects $(n=18)$ cultured in medium (white) or with rA $\beta_{42}$ (black). Statistical analysis was performed by ANOVA test. Significant values are indicated, $\mathrm{p}_{1}=\mathrm{CD} 25$ expression on unstimulated (medium) AD cells vs. unstimulated $\mathrm{HC}$ cells; $\mathrm{p}_{2}=\mathrm{CD} 69$ expression on $\mathrm{rA} \beta_{42}$-stimulated cells from $\mathrm{AD}$ vs. $\mathrm{rA} \beta_{42}$-stimulated cells from $\mathrm{HC}$. Concerning $\mathrm{B}$ cells, no significant differences were observed for CD25 expression on rA $\beta_{42}$-stimulated cells from AD vs. rA $\beta_{42}$-stimulated cells from HC, for CD69 expression on unstimulated cells (medium) AD vs. unstimulated HC cells, nor for both CD80 and HLA-DR between the groups studied. 


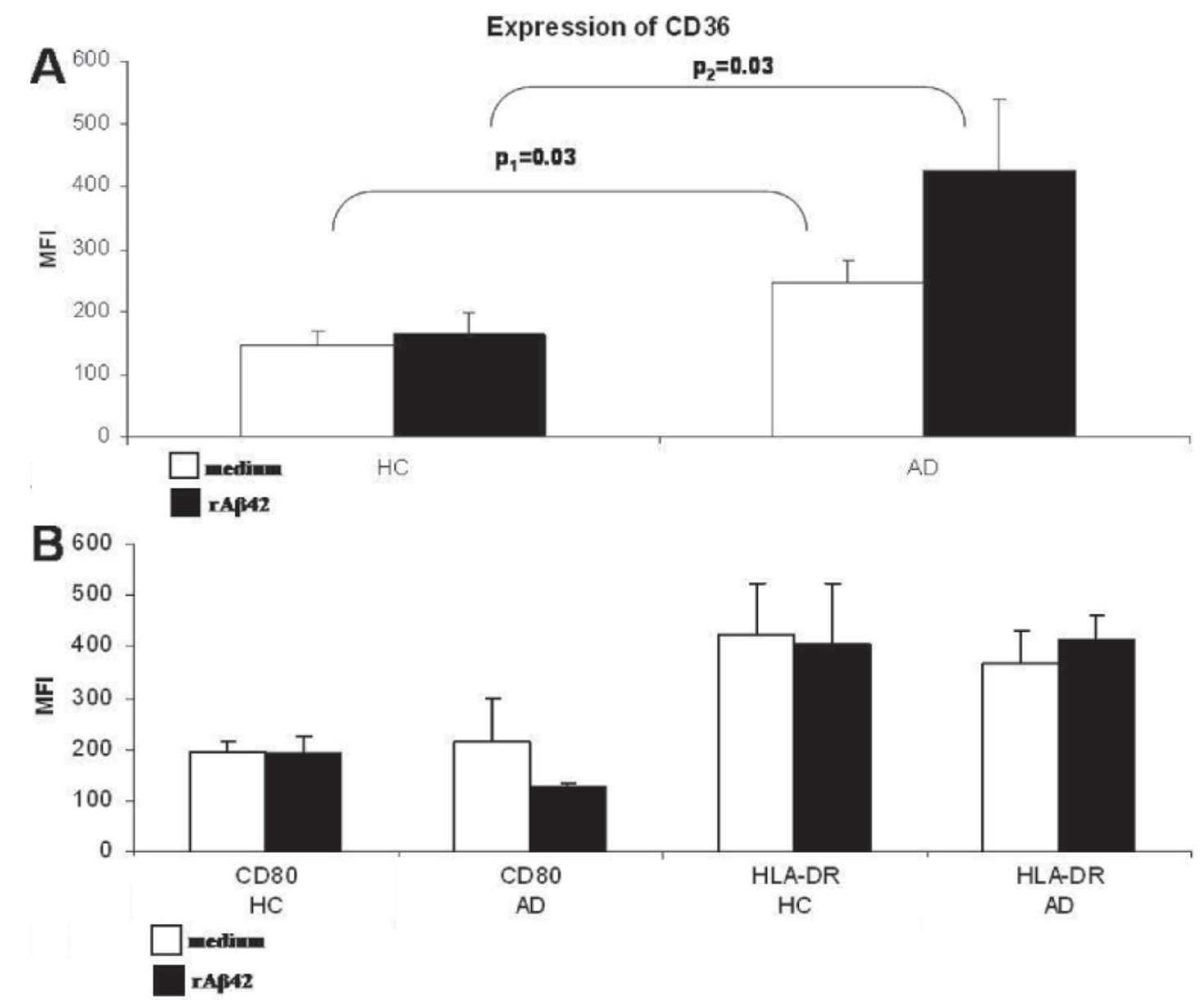

Fig. 3. MFI (Mean \pm SEM) of expression of CD36 (panel A) and CD80 and HLA-DR (panel B) on monocytes (CD14+) of HC $(n=15)$ and $\mathrm{AD}(n=18)$ subjects cultured in medium (white) or with $\mathrm{rA} \beta_{42}$ (black). Statistical analysis was performed by ANOVA test. Significant values are indicated, $\mathrm{p}_{1}=$ unstimulated (medium) $\mathrm{AD}$ cells vs. unstimulated $\mathrm{HC}$ cells, $\mathrm{p}_{2}=\mathrm{rA} \beta_{42}$-stimulated cells from $\mathrm{AD}$ vs. $\mathrm{rA} \beta_{42}$-stimulated cells from HC. No significant differences were observed for CD36 expression on unstimulated cells (medium) HC vs. stimulated HC cells, and on unstimulated (medium) AD cells vs. stimulated AD cells nor for the expression of CD80 and HLA-DR in the groups studied.

of circulating B lymphocytes of AD patients compared to HC. No significant differences have been instead observed between the two groups concerning the other lymphocyte subsets.

\section{PBMC activation}

To study the response to $\mathrm{A} \beta$, we stimulated PBMCs from $18 \mathrm{AD}$ and $15 \mathrm{HC}$ (see Materials and Methods) with the oligomeric form of $\mathrm{rA} \beta_{42}$ and analyzed the expression of the activation markers CD25 and CD69 on T and B lymphocytes, and of CD80 and HLA-DR on B lymphocytes.

We report (Fig. 2a) a significantly higher expression of CD25 on unstimulated $\mathrm{T}$ cells from AD patients compared to unstimulated $\mathrm{T}$ cells from $\mathrm{HC}$, whereas the stimulation by $\mathrm{rA} \beta_{42}$ does not induce significant differences between the two groups. On the contrary, CD69 is not significantly higher in unstimulated T cells from $A D$ patients and is significantly overexpressed after stimulation by $\mathrm{rA} \beta_{42}$. The expression of $\mathrm{CD} 25$, CD69, HLA-DR, and CD80 on B cells showed no significant differences, after stimulation, between the two groups studied. We again observed that lymphocytes of AD patients showed a basically higher, but not significant, expression of some of these activation markers (Fig. 2b, c).

We have also evaluated the activation of monocytes after stimulation by $\mathrm{rA} \beta 42$. We have observed a higher basal expression of CD36, a class B scavenger receptor that interacts with fibrillar $\mathrm{A} \beta[25,29]$, and a significant different expression of this receptor after stimula- 

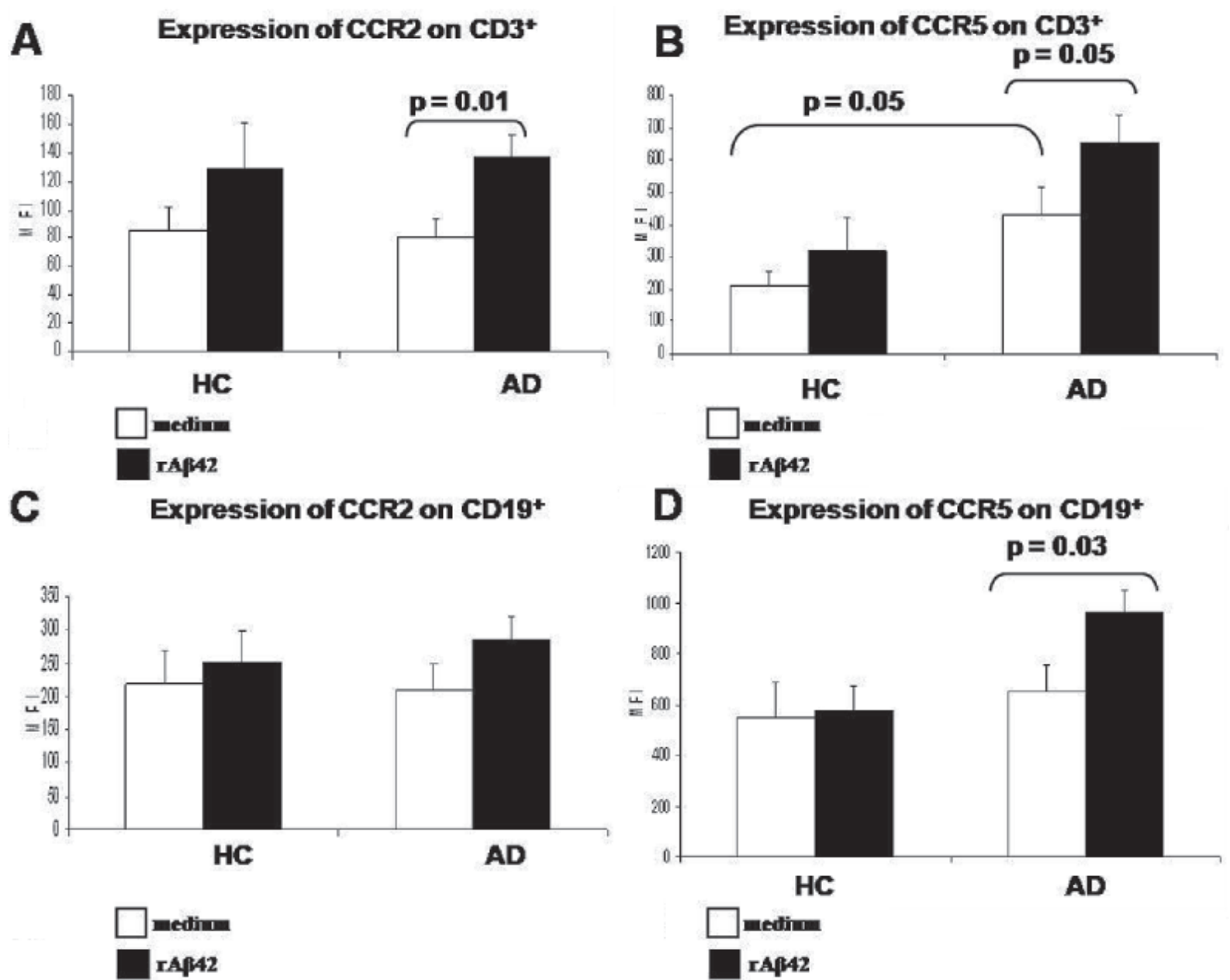

Fig. 4. MFI (Mean \pm SEM) expression of CCR2 and CCR5 on CD3+ T cells (panels a, b) and CD19 B (panels c, d) peripheral lymphocytes obtained from $15 \mathrm{HC}$ subjects and $18 \mathrm{AD}$ patients and cultured for $48 \mathrm{~h}$ in presence (black) or absence (white) of rA $\beta_{42}$. Statistical analysis was performed by ANOVA test. P values are calculated comparing the MFI \pm SEM of positive cells obtained from unstimulated and rA $\beta_{42}$-stimulated cells. Comparing unstimulated vs. stimulated cells we obtain significant values in: a) CCR2 expression on T cells from AD patients, (unstimulated vs. stimulated $p=0.01$ ); b) CCR5 expression on T cells from AD patients, (unstimulated vs. stimulated $p=0.05$ ); c) CCR2 expression on B cells from AD patients, (unstimulated vs. stimulated not significant); d) CCR5 expression on B cells from AD patients, (unstimulated vs. stimulated $p=0.03$ ). Concerning the unstimulated PBMCs significant difference are observed comparing CCR5 expression on T cells from HC and AD. Indeed there is a higher basal expression of CCR5 on AD patients (HC vs. AD $p=0.05$ ).

tion by $\mathrm{rA} \beta_{42}$ between patients and controls (Fig. 3a). In contrast, analyzing the expression of CD80 and of HLA-DR on monocytes, we have not seen any variation between the groups studied (Fig. 3b).

In a further set of experiments, we have evaluated the expression of CCR2 (MCP-1 receptor), CCR3 (RANTES and eotaxin receptor) and of CCR5 (MIP$1 \alpha$, MIP-1 $\beta$, and RANTES receptor) on $\left.\mathrm{T}_{(\mathrm{CD}}{ }^{+}\right)$and $\mathrm{B}\left(\mathrm{CD} 19^{+}\right)$lymphocytes.

As shown (Fig. 4a-d), CCR2 (Fig. 4a) and CCR5 (Fig. 4b) are overexpressed on $\mathrm{T}$ cells stimulated by $\mathrm{rA} \beta_{42}$, in both groups, although the significance was attained only in $\mathrm{AD}$ patients. In addition, the basal expression of CCR5 on the CD3+ cells is significantly higher in AD patients. The evaluation of the same receptors on $\mathrm{B}$ cells, after activation by $\mathrm{rA} \beta_{42}$, shows a significantly greater expression of CCR5 in AD patients, and not in controls. No differences were observed for CCR2 expression on CD19+ cells (Fig. 4c, d) as well as for CCR3 expression on T and B cells (data not shown).

The stimulation of cells from HC and AD by PHA or $\alpha$-CD3, used as further control, does not induce the expression of these chemokine receptors either in $\mathrm{HC}$ or $\mathrm{AD}$ patients. Figure 5 shows a typical experiment that compares the response of cells from $\mathrm{AD}$ pa- 

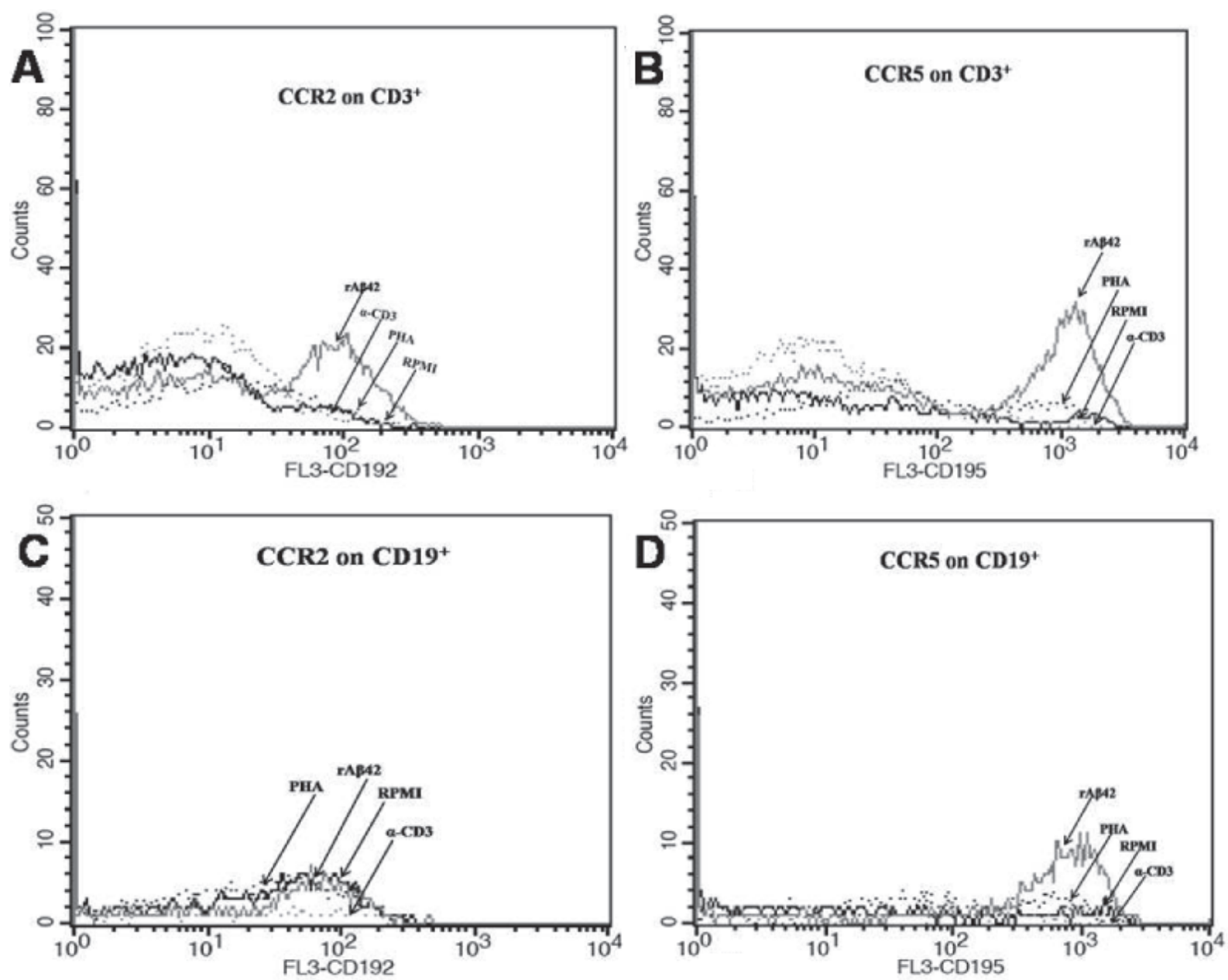

Fig. 5. Representative expression of CCR2 and CCR5 on CD3+ T cells (panels a, b) and CD19 B cells (panels c, d) obtained from one AD patient, and cultured for $48 \mathrm{~h}$ in presence of PHA $(\ldots \ldots), \alpha$-CD3 $(\ldots \ldots), \mathrm{rA} \beta_{42}(-)$, or none (RPMI) (一).

tients to the different stimuli used (PHA, $\alpha$-CD3, and $\mathrm{rA} \beta_{42}$ ). As shown (Fig. 5a, b), CD3 cells overexpress CCR2 (panel A) and CCR5 (panel B) when stimulated by $\mathrm{rA} \beta_{42}$, whereas the stimulation by either PHA or $\alpha$-CD3 gives a fluorescence intensity like that of unstimulated T cells. Panel C and panel D depict the results obtained stimulating CD19 B cells. As shown, no changes are observed in the expression of CCR2, using $\mathrm{rA} \beta_{42}$, PHA or $\alpha$-CD3. Activation by $\mathrm{rA} \beta_{42}$ causes an increased of expression of CCR5 on B cells, whereas the stimulation by either PHA or $\alpha$-CD3 gives a fluorescence intensity like that of unstimulated B cells.

AD patients $(N=18)$ of this subgroup showed the same changes in lymphocyte populations (i.e., B lymphocyte decrease) as well as in the initial group (7.0 \pm 2.2 versus $7.0 \pm 3.7)$. None of these results were af- fected by the gender and the MMSE of AD patients; in particular no differences have been observed comparing data obtained from subjects with severe $(<17)$ versus moderate $\mathrm{AD}$.

\section{Cytokine production}

We have analyzed the production of cytokines, growth factors, and chemokines in supernatants obtained from AD- and HC-PBMC cultured for $48 \mathrm{~h}$ in the presence/absence of the oligomeric form of $\mathrm{rA} \beta_{42}$. As shown in Table 2, after stimulation by $\operatorname{rA} \beta_{42}$, PBMC obtained from AD patients significantly increased the production of both pro-inflammatory cytokines (IL- $1 \beta$, IL-6, IFN- $\gamma$, TNF- $\alpha$ ) and anti-inflammatory cytokines (IL-10, IL-1ra) as well as some growth factors (GM- 
Table 2

Percent of increase of cytokines, growth factors, and chemokines secretion by PBMCs of 15 HC and 18 AD patients in presence/absence of $\mathrm{rA} \beta_{42}$. The percentage was calculated using the following formula: stimulated-unstimulated/unstimulated $\mathrm{x} 100$. In bracket $\%$ of increase of p25-p75 values. Significance has been evaluated by ANOVA test. n.s. = not significant

\begin{tabular}{|c|c|c|c|c|}
\hline Cytokines & $\begin{array}{l}\mathrm{rA} \beta_{42} \mathrm{HC} \text { vs. medium HC Increase }(\%) \\
\text { (median and } \mathrm{p}-25-\mathrm{p} 75 \text { values) }\end{array}$ & $\begin{array}{l}\mathrm{rA} \beta_{42} \mathrm{AD} \text { vs. medium AD Increase }(\%) \\
\text { (median and p-25-p75 values) }\end{array}$ & $\mathrm{p}_{1}$ & $\mathrm{p}_{2}$ \\
\hline $\mathrm{IL}-1 \beta$ & $4(0-22)$ & $211(133-285)$ & n.s. & 0.01 \\
\hline IL-1ra & $66(0-258)$ & $202(152-288)$ & n.s. & 0.006 \\
\hline IL-6 & $0(0-151)$ & $410(280-532)$ & n.s. & 0.01 \\
\hline $\mathrm{IFN}-\gamma$ & $0(0-52)$ & $106(84-134)$ & n.s. & 0.002 \\
\hline TNF- $\alpha$ & $0(0-168)$ & $63(35-104)$ & n.s. & 0.02 \\
\hline IL-10 & $0(0-0)$ & $236(100-542)$ & n.s. & 0.03 \\
\hline \multicolumn{5}{|l|}{ Growth Factors } \\
\hline GM-CSF & $0(0-90)$ & $77(62-100)$ & n.s. & 0.003 \\
\hline VEGF & $0(0-322)$ & $32(10-82)$ & n.s. & n.s. \\
\hline PDGF bb & $57(0-283)$ & $14(0-26)$ & n.s. & n.s. \\
\hline G-CSF & $(0-280)$ & 547 (367-1367) & n.s. & 0.01 \\
\hline \multicolumn{5}{|l|}{ Chemokines } \\
\hline Eotaxin & $0(0-128)$ & $114(98-141)$ & n.s. & 0.003 \\
\hline MIP- $1 \alpha$ & $188(0-577)$ & $1710(163-5032)$ & n.s. & n.s. \\
\hline MIP-1 $\beta$ & $74(0-377)$ & 465 (152-639) & n.s. & 0.02 \\
\hline RANTES & $275(0-955)$ & $123(57-206)$ & n.s. & 0.05 \\
\hline MCP-1(MCAF) & $0(0-0)$ & $0(0-0)$ & n.s. & n.s. \\
\hline
\end{tabular}

$\mathrm{p}_{1}=$ Significance of differences between Medium and $\mathrm{rA} \beta_{42}$ of $\mathrm{HC} ; \mathrm{p}_{2}=$ Significance of differences between Medium and $\mathrm{rA} \beta_{42}$ of $\mathrm{AD}$.

CSF, G-CSF) and some chemokines (eotaxin, MIP$1 \beta$, RANTES) when compared to the cells cultured in medium. On the contrary, cells obtained from $\mathrm{HC}$ do not show any significant increase in the production of these cytokines.

By analyzing data according both to gender and to AD severity, no differences were observed. As previously stated, AD patients of this subgroup showed the same changes in lymphocyte populations (i.e., B lymphocyte decrease) as well as in the initial group.

\section{DISCUSSION}

Many studies have reported alterations of the immune system in $\mathrm{AD}$ and the involvement of both the innate and acquired branches of the immune system [3, 12]. In this paper, we report data obtained studying cells and factors involved in immune response in AD patients.

The "peripheral lymphocytes" topic has been examined by different groups with conflicting results [12, 20,26-28], and currently there is no general consensus on the modifications of lymphocyte subsets in AD patients [12]. Our study of AD lymphocyte subpopulations confirms the already described decrease of the absolute number and percentage of B cells when compared to HC lymphocytes [26-28], whereas the other subsets are not significantly different in patients and controls. This decreased number of B cells is already present in elderly when compared to young people [30]. Therefore, it suggests an exacerbation in AD of this feature linked to a reduced output of B cells from bone marrow [30]. This might be due to the well known systemic pro-inflammatory status of AD patients [3, 6-10,31] and present results. On the T cell side, the results reported in different studies are discordant with each other. In fact, whereas our data are in agreement with Speciale et al. [26], Xue et al. [28] show a significant reduction of CD3+, CD4+ and CD8+; RichartzSalzburger et al. [29] confirm the decrease of CD3+ T cells and CD8+ T cells, but showed a slightly increase of CD4+. On the other hand, as previously stated, dramatic alterations on CD4+ subsets in patients with mild AD have been reported by Larbi et al. [20]. These differences might be the result of methodological differences among the different studies, including inclusion criteria of both $\mathrm{AD}$ patients and $\mathrm{HC}$.

However, the finding that the $\mathrm{B}$ cell compartment is modified in $\mathrm{AD}$ patients compared to $\mathrm{HC}$, together with the increased expression of the chemokine receptor CCR5 on B cells, after stimulation by $\mathrm{rA} \beta_{42}$, suggests the involvement of B cells in the complex cellular interactions active in AD patients. On the other hand, $\mathrm{rA} \beta_{42}$ stimulation does not change the expression of the activation markers CD25 and CD69 on B cells: it is an unexpected result since $\mathrm{B}$ cells can produce antibodies against $\mathrm{A} \beta$ [32]. 
On the other hand, we report a good response of $\mathrm{T}$ cells to $\mathrm{A} \beta$; in fact the CD69 activation marker is overexpressed in $\mathrm{rA} \beta_{42}$-stimulated $\mathrm{AD}$ cells when compared to HC stimulated cells. Furthermore, the chemokine receptors CCR2 and CCR5 are overexpressed in $\mathrm{AD}$ cells after in vitro stimulation by $\mathrm{rA} \beta_{42}$. This is an interesting result since the reactivity and ability of $\mathrm{T}$ cells to respond to the chemokines that can be produced locally in the brain might explain the migration of $\mathrm{T}$ cells across the brain microvascular endothelial cells occurring in AD [12]. It is noteworthy that some activation markers and chemokine receptors are overexpressed in unstimulated AD cells when compared to controls. This is evidence of the proinflammatory status of AD [3,6-10,31]. The increase of CD25+ T lymphocytes in cells from AD patients cultured in medium only might suggest an increase of Treg $\left(\mathrm{CD} 4+\mathrm{CD} 25^{\text {high }}\right)$. However, using as marker of Treg FOXP3, Rosenkranz and colleagues [33] did not report their increase in PBMC just collected from AD patients when compared to elderly donors. On the contrary, Larbi and coworkers [20] show that CD4+CD25 high are reduced in PBMC just collected from AD when compared with both young and old donors. Our experimental conditions are different as we observe an increase of basal expression of CD25 on total CD3 cultured for $48 \mathrm{~h}$ with medium only. So, in our opinion, the increase of CD3+CD25+ cells in AD patients might be the consequence of the basal inflammatory milieu of AD patients [3,6-10,31].

The increased expression of the scavenger receptor CD36 on monocytes from AD subjects in unstimulated and stimulated cultures is also an intriguing result as circulating monocytes might efficiently bind plasmatic $\mathrm{A} \beta$. That causes the production of cytokines, chemokines, and reactive oxygen species, hence activating the signaling cascade useful for cellular migration, adhesion, and phagocytosis. In addition, the engagement of monocytes might render these cells more efficient in T cell activation [34].

Our data show that, in addition to expressing chemokine receptors, $\mathrm{PBMC}$ in vitro stimulated by $\mathrm{rA} \beta_{42}$ are able to produce different chemokines and cytokines, rendering these cells active players in the inflammatory response in AD patients. The study of in vitro production of cytokines shows a significantly higher production of inflammatory cytokines IL- $1 \beta$, IL-6, and TNF- $\alpha$ and of IFN- $\gamma$ by AD in vitro stimulated PBMC. This is not a surprising result as inflammation is a characteristic of $\mathrm{AD}$ [3] and a high responder cytokine profile is associated with $\mathrm{AD}[9,10,32]$. We also report an increase of anti-inflammatory cytokines IL-10 and IL-1ra, and we hypothesize that this increase in vitro production should balance the higher in vitro production of pro-inflammatory cytokines. However, as previously stated, there is an efflux of amyloid from CNS that can prime lymphocytes. Some authors have demonstrated a reduction of both pro- and antiinflammatory cytokines, hence assuming a general impairment of immune functions in AD patients, whereas others have demonstrated a decrease of IL-10, an increase of MIP1- $\alpha$ and an increase of IFN- $\gamma$, respectively $[12,18,19,26]$. Methodological differences (mitogen or $\mathrm{A} \beta$ stimulation) among the different studies, including inclusion criteria of both $\mathrm{AD}$ patients and healthy controls, might explain the great variability of data. Since monocytes are the main source of IL-6 and TNF- $\alpha$ and they possibly bind efficiently $\mathrm{A} \beta_{42}$ via CD36, the pattern of cytokine production observed in the present paper is that to be expected.

It has been demonstrated that peripheral T lymphocytes of AD patients produce higher MIP- $1 \alpha$ levels than age-matched controls [18]. This observation together with the expression of the MIP- $1 \alpha$ receptor CCR5 on the human brain microvascular endothelial cells (HBMEC), might explain the migration of $\mathrm{T}$ cells across the blood-brain barrier. Microglial cells also produce MIP- $1 \alpha$. It has been demonstrated that MCP-1 via CCR2 expressed on brain endothelial cells contribute to increased brain endothelial permeability $[12,18,35-$ 37]. Here we show a higher expression of CCR5 on $\mathrm{T}$ and B lymphocytes, and of CCR 2 on T cells stimulated in vitro by $\mathrm{rA} \beta_{42}$, participating in a vicious circle in the brain.

In contrast to these data, in our system we do not observe any significant overproduction of MIP- $1 \alpha$ in PBMC in vitro stimulated by $\mathrm{rA} \beta_{42}$. This discrepancy might be due to the different experimental system since the production-binding of MIP- $1 \alpha$ "in vivo" or "in vitro" was assessed using HBMEC [18]. As previously described by others [38], our AD patients show increased production of RANTES binding CCR5 also, when compared to unstimulated cells of the same donors. Finally, the results of MCP-1 production are very unpredictable in the different individuals of the two subject cohorts, so it is impossible to draw any conclusion.

A higher level of chemokines after stimulation with PHA has been demonstrated by other authors [38]. We have not evaluated the production of cytokines and chemokines from cells stimulated with $\alpha \mathrm{CD} 3$ or PHA, but in our system the stimulation with mitogens does 
not change the expression of CCR5 and CCR2 on T and $B$ cells.

Finally, cytokine, growth factor, and chemokine production was obtained in a bulk culture preparation as we are interested in an ex-vivo model of interaction between different cells and factors. Furthermore, no proliferation assay was performed, because in our system no changes in IL-2 production were detectable after stimulation by $\mathrm{rA} \beta_{42}$ in both $\mathrm{AD}$ and $\mathrm{HC}$ (data not shown).

On the whole, our data demonstrate that immuneinflammatory parameters are modified in PBMC obtained from $\mathrm{AD}$ patients and stimulated in vitro by $\mathrm{rA} \beta_{42}$. Data on involvement of the immune system in $\mathrm{AD}$ are controversial and difficult to fully understand. The results obtained in our study can be the mirror of $\mathrm{T}$ and microglial abilities in AD patients. Therefore, these data on the activation of peripheral lymphocytes by $\mathrm{rA} \beta_{42}$ support the occurrence in $\mathrm{AD}$ of the systemic activation of immune-inflammation $[31,39,40]$, and, on the other hand demonstrated by the high level of basal activation. We know that the brain is not an immunologically privileged site since peripheral immune cells can influence local reactions and can be influenced by local immune-inflammatory responses [12].

We contribute new information about soluble factors and cellular ligands that might be involved in the pathogenesis or in the tissue damage observed in $\mathrm{AD}$ patients. However, our study is an observational one; hence we cannot draw a conclusion on its contribution to the pathophysiology of the disease. The knowledge that senile plaques, a hallmark of AD (together with neurofibrillary tangles) are formed by $\mathrm{A} \beta$, has suggested the design of immunotherapies with the aim of removing or reducing the senile plaques from the brain. Unfortunately clinical trials of $\mathrm{A} \beta$ vaccination of $\mathrm{AD}$ patients show an unacceptable rate of meningoencephalitis [41]. On the other hand, intravenous immunoglobulin (IVIg) has been proposed as a potential agent for AD immunotherapy because it contains antibodies against $\mathrm{A} \beta$. Accordingly, a retrospective case-control analysis demonstrated that previous treatment with IVIg is associated with a reduced risk of developing AD [42]. Thus, this kind of study might be useful to obtain biomarkers of AD for monitoring the effectiveness of therapeutic interventions [43].

\section{ACKNOWLEDGMENTS}

Mariavaleria Pellicanò and Silvio Buffa are $\mathrm{PhD}$ students at the Pathobiology $\mathrm{PhD}$ course (directed by
Calogero Caruso) of Palermo University and this work is submitted in partial fulfilment of the requirement for their PhD degree. This work was supported by grants from the Italian Ministry of Education, University and Research to CC and GCR

Authors' disclosures available online (http://www.jalz.com/disclosures/view.php?id=354).

\section{REFERENCES}

[1] Nelson PT, Braak H, Markesbery WR (2009) Neuropathology and cognitive impairment in Alzheimer disease: a complex but coherent relationship. J Neuropathol Exp Neurol 68, 1-14.

[2] Rafili MS, Aisen PS (2009) Recent developments in Alzheimer's disease therapeutics. BMC Med 7, 7.

[3] Vasto S, Candore G, Listì F, Balistreri CR, Colonna-Romano G, Malavolta M, Lio D, Nuzzo D, Mocchegiani E, Di Bona D, Caruso C (2008) Inflammation, genes and zinc in Alzheimer's disease. Brain Res Rev 58, 96-105.

[4] Querfurth HW, LaFerla FM (2010) Alzheimer's disease. $N$ Engl J Med 362, 329-344.

[5] Akiyama H, Barger S, Barnum S, Bradt B, Bauer J, Cole GM, Cooper NR, Eikelenboom P, Emmerling M, Fiebich BL, Finch CE, Frautschy S, Griffin WS, Hampel H, Hull M, Landreth G, Lue L, Mrak R, Mackenzie IR, McGeer PL, O’Banion MK, Pachter J, Pasinetti G, Plata-Salaman C, Rogers J, Rydel R, Shen Y, Streit W, Strohmeyer R, Tooyoma I, Van Muiswinkel FL, Veerhuis R, Walker D, Webster S, Wegrzyniak B, Wenk G, Wyss-Coray T (2000) Inflammation in Alzheimer's disease. Neuroinflammation Working Group. Neurobiol Aging 21, 383421.

[6] Teeling JL, Perry VH (2009) Systemic infection and inflammation in acute CNS injury and chronic neurodegeneration: underlying mechanisms. Neuroscience 158, 1062-1073.

[7] Vasto S, Candore G, Duro G, Lio D, Grimaldi MP, Caruso C (2007) Alzheimer's disease and genetics of inflammation: a pharmacogenomic vision. Pharmacogenomics 8, 1735-1745.

[8] Listi F, Caruso C, Lio D, Colonna-Romano G, Chiappelli M, Licastro F, Candore G (2010) Role of COX-2 and 5-LO polymorphisms in Alzheimer's disease in a population from Northern Italy: implication for pharmacogenomics. J Alzheimers Dis 19, 551-557.

[9] Di Bona D, Candore G, Franceschi C, Licastro F, ColonnaRomano G, Cammà C, Lio D, Caruso C (2009) Systematic review by meta-analyses on the possible role of TNF-alpha polymorphisms in association with Alzheimer's disease. Brain Res Rev 61, 60-68.

[10] Di Bona D, Plaia A, Vasto S, Cavallone L, Lescai F, Franceschi C, Licastro F, Colonna-Romano G, Lio D, Candore G, Caruso C (2008) Association between the interleukin-1beta polymorphisms and Alzheimer's disease: a systematic review and meta-analysis. Brain Res Rev 59, 155-163.

[11] Wyss-Coray $T$ (2006) Inflammation in Alzheimer Disease: Driving force, bystander or beneficial response? Nat Med 12, 1005-1015.

[12] Britschgi M, Wyss-Coray T (2007) Systemic and acquired immune responses in Alzheimer's disease. Int Rev Neurobiol 82, 205-233.

[13] Rogers J, Luber-Narod J, Styren SD, Civin WH (1998) Expression of immune system associated antigens by cells of the 
human central nervous system: Relationship to the pathology of Alzheimer's disease. Neurobiol Aging 9, 339-349.

[14] Fiala M, Lin J, Ringman J, Kermani-Arab V, Tsao G, Patel A, Lossinsky AS, Graves MC, Gustavson A, Sayre J, Sofroni E, Suarez T, Chiappelli F, Bernard G (2005) Ineffective phagocytosis of amyloid-beta by macrophages of Alzheimer's disease patients. J Alzheimers Dis 7, 221-232.

[15] Monsonego A, Zota V, Karni A, Krieger JI, Bar-Or A, Bitan G, Budson AE, Sperling R, Selkoe DJ, Weiner HL (2003) Increased $\mathrm{T}$ cell reactivity to amyloid beta protein in older humans and patients with Alzheimer's disease. J Clin Invest 112, 415-422.

[16] Weksler ME, Relkin N, Turkenich R, LaRusse S, Zhou L, Szabo P (2002) Patients with Alzheimer disease have lower levels of serum anti-amyloid peptide antibodies than healthy elderly individuals. Exp Gerontol 37, 943-948.

[17] Reale M, Iarlori C, Gambi F, Lucci I, Salvatore M, Gambi D (2005) Acetylcholinesterase inhibitors effects on oncostatin$\mathrm{M}$, interleukin-1 beta and interleukin-6 release from lymphocytes of Alzheimer's disease patients. Exp Gerontol 40, 165171.

[18] Man SM, Ma YR, Shang DS, Zhao WD, Li B, Guo DW, Fang WG, Zhu L, Chen YH (2007) Peripheral T cells overexpress MIP-1alpha to enhance its transendothelial migration in Alzheimer's disease. Neurobiol Aging 28, 485-496.

[19] Reale M, Iarlori C, Feliciani C, Gambi D (2008) Peripheral chemokine receptors, their ligands, cytokines and Alzheimer's disease. J Alzheimers Dis 14, 147-159.

[20] Larbi A, Pawelec G, Witkowski JM, Schipper HM, Derhovanessian E, Goldeck D, Fulop T (2009) Dramatic shifts in circulating CD4 but not CD8 T cell subsets in mild Alzheimer's disease. J Alzheimers Dis 17, 91-103.

[21] McKhann G, Drachman D, Folstein M, Katzman R, Price D, Stadlan EM (1984) Clinical diagnosis of Alzheimer's disease: report of the NINCDS-ADRDA Work Group under the auspices of Department of Health and Human Service Task Force on Alzheimer's Disease. Neurology 34, 939-944.

[22] American Psychiatric Association (1987) Diagnostic and statistical manual of mental disorders: DSM-III-R, 3rd revised ed. Washington (DC), American Psychiatric Association.

[23] Reale M, Iarlori C, Gambi F, Feliciani C, Salone A, Toma L, DeLuca G, Salvatore M, Conti P, Gambi D (2004) Treatment with an acetylcholinesterase inhibitor in Alzheimer patients modulates the expression and production of the proinflammatory and anti-inflammatory cytokines. J Neuroimmunol 148, 162-171.

[24] Carrotta R, Di Carlo M, Manno M, Montana G, Picone P, Romancino D, San Biagio PL (2006) Toxicity of recombinant beta-amyloid prefibrillar oligomers on the morphogenesis of the sea urchin Paracentrotus lividus. FASEB J 20, 1916-1917.

[25] Coraci IS, Husemann J, Berman JW, Hulette C, Dufour JH, Campanella GK, Luster AD, Silverstein SC, El-Khoury JB (2002) CD36, a class B scavenger receptor, is expressed on microglia in Alzheimer's disease brains and can mediate production of reactive oxygen species in response to beta-amyloid fibrils. Am J Pathol 160, 101-112.

[26] Speciale L, Calabrese E, Saresella M, Tinelli C, Mariani C, Sanvito L, Longhi R, Ferrante P (2007) Lymphocyte subset patterns and cytokine production in Alzheimer's disease patients. Neurobiol Aging 28, 1163-1169.

[27] Xue S, Xu D, Yang X, Dong W (2009) Alterations in lymphocyte subset patterns and co-stimulatory molecules in patients with Alzheimer disease. Chin Med J 122, 1469-1472.

[28] Raichartz-Salzburger E, Batra A, Stransky E, Laske C, Kohler
N, Bartels M, Cichkremer G, Schott K (2007) Altered lymphocyte distribution in Alzheimer's disease. J Psych Res 41, 174-178.

[29] El Khoury JB, Moore KJ, Means TK, Leung J, Terada K, Toft M, Freeman MW, Luster AD (2003) CD36 mediates the innate host response to $\beta$-amyloid. J Exp Med 197, 1657-1666.

[30] Colonna-Romano G, Bulati M, Aquino A, Vitello S, Lio D, Candore G, Caruso C (2008) B cell immunosenescence in the elderly and in centenarians. Rejuvenation Res 11, 433-439.

[31] Candore G, Bulati M, Caruso C, Castiglia L, Colonna-Romano G, Di Bona D, Duro G, Lio D, Pellicanò M, Rizzo C, Scapagnini G, Vasto S (2010) Inflammation, cytokines, immune response, ApoE and cholesterol, oxidative stress in Alzheimer disease: therapeutics implications. Rejuvenation Res 13, 301313.

[32] Gaskin F, Finley J, Fang Q, Xu S, Fu SM (1993) Human antibodies reactive with beta-amyloid protein in Alzheimer's disease. J Exp Med 177, 1181-1186.

[33] Rosenkranz D, Weyer S, Tolosa E, Gaenslen A, Berg D, Leyhe T, Gasser T, Stoltze L (2007) Higher frequency of regulatory $\mathrm{T}$ cells in the elderly and increased suppressive activity in neurodegeneration. J Neuroimmunol 188, 117-127.

[34] Stuart LM, Bell SA, Stewart CR, Silver JM, Richard J, Goss JL, Tseng AA, Zhang A, El Khoury JB, Moore KJ (2007) $\mathrm{CD} 36$ signals to the actin cytoskeleton and regulates microglial migration via a p130Cas complex. J Biol Chem 282, 2739227401.

[35] Karpus WJ, Lukacs NW, McRae BL, Strieter RM, Kunkel SL, Miller SD (1995) An important role for the chemokine macrophage inflammatory protein- 1 alpha in the pathogenesis of the T cell-mediated autoimmune disease, experimental autoimmune encephalomyelitis. J Immunol 155, 5003-5010.

[36] Wekerle H (1993) T-cell autoimmunity in the central nervous system. Intervirology 35, 95-100.

[37] Stamatovic SM, Keep RF, Kunkel SL, Andjelkovic AV (2003) Potential role of MCP-1 in endothelial cell tight junction 'opening': signaling via Rho and Rho kinase. J Cell Sci 116, 4615-4628.

[38] Iarlori C, Gambi D, Gambi F, Lucci I, Feliciani C, Salvatore M, Reale M (2005) Expression and production of two selected beta-chemokines in peripheral blood mononuclear cells from patients with Alzheimer's disease. Exp Gerontol 40, 605-611.

[39] Holmes C, Cunningham C, Zotova E, Woolford J, Dean C, Kerr S, Culliford D, Perry VH (2009) Systemic inflammation and disease progression in Alzheimer disease. Neurology 73, 768-774.

[40] Di Bona D, Scapagnini G, Candore G, Castiglia L, ColonnaRomano G, Duro G, Nuzzo D, Iemolo F, Lio D, Pellicanò M, Scafidi V, Caruso C, Vasto S (2010) Immune-inflammatory responses and oxidative stress in Alzheimer's disease: therapeutic implications. Curr Pharm Des 16, 684-691.

[41] Orgogozo JM, Gilman S, Dartigues JF, Laurent B, Puel M, Kirby LC, Jouanny P, Dubois B, Eisner L, Flitman S, Michel BF, Boada M, Frank A, Hock C (2003) Subacute meningoencephalitis in a subset of patients with AD after Abeta42 immunization. Neurology 61, 46-54.

[42] Fillit H, Hess G, Hill J, Bonnet P, Toso C (2009) IV immunoglobulin is associated with a reduced risk of Alzheimer disease and related disorders. Neurology 73, 180-185.

[43] Scapagnini G, Caruso C, Vasto S, Pascale A, Romeo L, D’Agata V, Intrieri M, Sapere N, Li Volti G (2010) Genetic risk factors and candidate biomarkers for Alzheimer's disease. Front Biosci (Schol Ed) 2, 616-622. 